Коць, Тетяна. «Реалізація стилістичного потенціалу оцінності в українській мові». Лінгвостилістичні студіï, вип. 13, 2020, с. 84-92.

Kots, Tetiana. "Actualization of the Evaluativeness Stylistic Potential in the Ukrainian Language". Linguostylistic Studies, iss. 13, 2020, pp. 84-92.

УДК 811.323:130.2

https://doi.org/10.29038/2413-0923-2020-13-84-92

\title{
РЕАЛІЗАЦІЯ СТИЛІСТИЧНОГО ПОТЕНЦІАЛУ ОЦІННОСТІ В УКРАЇНСЬКІЙ МОВІ
}

\author{
Тетяна Коць \\ Інститут української мови НАН України, \\ Київ, Україна
}

У статті з'ясовано функціонально-стилістичні параметри оцінності як лінгвістичної категорії., яка охоплює різнорівневі мовні одиниці з оцінною семантикою i передає позитивне або негативне ставлення мовця до названого предмета, явища, поняття.

Позитивна або негативна змістова шкала оцінності формується відповідно до визначених у суспільстві соціальних, національно-культурних, моральних цінностей. Логічна (раціональна) і емоційна (ірраціональна) оцінка в тексті взаємодіють. Логічну оцінність мотивують об'єктивні думки, а емоційну - почуття суб'єкта до об'єкта (особи, предмета, явища, події тощо). Одиницями логічної оцінності є слова і словосполучення 3 позитивнооцінною i негативнооцінною семантикою 3 інтелектуальної сфери мовомислення, а одиницями емоційної - експресивно-конотативні мовні засоби. Оцінювання відбувається шляхом вживання мовних одиниць, зареєстрованих у словниках або в пам'яті носіїв мови з погляду їхніх ціннісних орієнтирів.

Стилістичний потенціал оцінності в тексті розкритий на лексичному, фразеологічному, синтаксичному рівнях. Тексти різні за стилем і змістом різняться за способом вираження в них вербальної аксіології.

Ключові слова: оцінність, позитивнооцінні засоби, негативнооцінні засоби, стилі літературної мови.

\section{ACTUALIZATION OF THE EVALUATIVENESS STYLISTIC POTENTIAL IN THE UKRAINIAN LANGUAGE}

\author{
Tetiana Kots \\ Institute of the Ukrainian Language of National Academy of Sciences of Ukraine, \\ Kyiv, Ukraine
}

The article clarifies the functional and stylistic parameters of evaluation as a linguistic category, which covers different levels of language units with evaluative semantics and conveys the positive or negative attitude of the speaker to the subject, phenomenon, concept.

The scale of positive or negative semantic evaluation is formed in accordance with the established social, national-cultural, and moral values. Logical (rational) and emotional (irrational) assessment in the text interact. Logical evaluation is motivated by the objective

(c) Коць Т., Волинський національний університет імені Лесі Українки, 2020.

Це стаття відкритого доступу на умовах СC BY-NC 4.0 
thoughts, while emotional - by the feelings of the subject to the object (person, object, phenomenon, event, etc.). Units of logical evaluation are the words and phrases with positive and negative semantics from the intellectual sphere of linguistic thinking, and units of emotional - linguistic means with expressive connotation. Evaluation is provided via the use of language units registered in dictionaries or in the memory of native speakers in terms of their values: good and evil, true and false, justice and injustice, benefit and harm, beauty and ugliness, the allowed and forbidden. Evaluative semantics is revealed in the appropriate contextual conditions, in particular, in updating the structure and semantics of the components or stylistic marking of syntactic units.

The combination of logical and emotional evaluation allows for closely related to the communication situation pragmatic evaluation of the text as a whole. In particular, these are verbal acts of approval, encouragement, commitment (plus on the scale of evaluations) or, vice versa, condemnation, contempt (minus on the scale of evaluations), which are based on a joint bank of knowledge and norms of interlocutors.

The stylistic potential of evaluation in the text is revealed on lexical, phraseological, and syntactic levels. Texts, differing in style and content, differ in the ways they express verbal axiology.

Key words: evaluativeness, positive evaluative means, negative evaluative means, styles of literary language.

Вступ. Оцінність у текстах різних стилів літературної мови $\epsilon$ регулятором поведінки автора у виборі мовних засобів, референційних об’єктів для вербалізації, стратегії і тактики вербальної взаємодії. Цінності визначають мовну поведінку, виступаючи основою мотивації і функціонуючи в системі аксіологічних орієнтирів народу.

Мовні механізми оцінності, емотивності та експресивності (семантико-стилістичних засобів суб'єктивного увиразнення мови) вивчають переважно в синхронному аспекті на різних рівнях мовної структури (М. М. Пилинський, С. Я. Єрмоленко, В. А. Чабаненко, С. П. Бибик, О. А. Стишов, О.О. Селіванова, В. М.Адмоні, О. М. Вольф, Є. М.ГалкінаФедорук, В. О. Жеребков, О. І. Москальська, В. І. Охріменко, В. М. Телія, В. I. Шаховський, О. Й. Шендельс та ін.).

Лінгвісти, як і логіки, оцінність тлумачать як думку про предмет, яка виражає його характеристику з погляду категорії цінності (Столярова 161). У позамовній сфері «під цінністю розуміють кожен предмет будь-якої вартості, прагнення, бажання, захоплення тощо» (Ивин 12).

Усебічного дослідження потребують механізми стилістичної оцінності та їх текстової реалізації. Метою цієї статті є обгрунтування оцінності як стилістичної категорії, аналіз функціонування мовних засобів аксіології в різних стилях сучасної української літературної мови.

Матеріал і методи дослідження. Матеріалом дослідження є тексти різних стилів літературної мови - публіцистичного, наукового, художнього, релігійного, офіційно-ділового, що уможливило визначення стильових диференційних ознак оцінності. Достовірність отриманих результатів i висновків забезпечило використання загальнолінгвістичних та рецептивностилістичних методів: функціонально-стилістичного методу (для 
встановлення диференційних ознак оцінності як категорії); варіантологічного аналізу (для фіксації варіантів стильової реалізації оцінності); прескриптивнодескриптивного аналізу (для встановлення кореляцій між прескриптивною нормою і мовною практикою); семантико-аксіологічного аналізу (для з'ясування оцінних механізмів різних стилів літературної мови).

Результати дослідження та дискусія. Оцінність виявляє зв'язок з емоційністю, експресивністю, проте не ототожнюється 3 названими поняттями. С.Я.Єрмоленко зазначає, що «емоційне в мові завжди експресивне, але не кожне експресивне явище належить до емоційних» (157). Емоційні й експресивні одиниці містять негативну або позитивну конотацію, але оцінність - поняття ширше. Оцінку можуть передавати й нейтральні мовні засоби, зокрема з інтелектуальної сфери мовомислення, які вносять елемент об'єктивного осмислення понять і явищ історичної доби. Емоційна оцінка, навпаки, вносить відчутний елемент суб'єктивізму в мову різних стилів літературної мови. С. М. Іваненко емоційну оцінку вважає і «елементом естетичної, а також підгрунтям раціональної оцінки, тому що емоція - це біопсихосоціальна одиниця, і оцінка, побудована на ії основі, не може бути чисто емоційною чи чисто раціональною» (590).

Н. Д. Арутюнова розрізняє сенсорні і абсолютні оцінки (Арутюнова 134-142). Сенсорні оцінки можуть бути гедоністичними (те, що подобається) і психологічними (інтелектуальними й емоційними). Абсолютна оцінка виражає естетичні й етичні цінності суспільства. Оцінка може бути також нейтральною. Німецький вчений Улл Фікс називає ії раціональною (Fix 10).

Оцінні конотації одних мовних одиниць на позначення цінностей суспільства вступають у семантичні відношення з іншими, встановлюючи перехід від суб'єктивного тлумачення до трактування в межах інших груп аксіономенів (Сорока 207). Е. М. Вольф ступінь зацікавленості суб'єкта поняттями, що «реалізується в семантиці деяких оцінних слів, так і в структурі висловлення в цілому» називає ефективністю (43).

Оцінність як термін лінгвостилістики охоплює різнорівневі мовні одиниці 3 оцінною семантикою і передає позитивне або негативне ставлення мовця до названого предмета, явища, поняття.

Позитивна або негативна змістова шкала оцінності формується відповідно до визначених у суспільстві соціальних, національнокультурних, моральних цінностей. Логічна (раціональна) і емоційна (ірраціональна) оцінка в тексті часто взаємодіють. Логічну оцінність мотивують об'єктивні думки, а емоційну - почуття суб'єкта до об'єкта (особи, предмета, явища, події тощо). Одиницями логічної оцінності $\epsilon$ слова i словосполучення 3 позитивнооцінною i негативнооцінною семантикою з інтелектуальної сфери мовомислення (мислитель, гуманіст, доброчесний науковець, розвинена інфраструктура, злодій, плагіатор, хабарник), а одиницями емоційної - експресивно-конотативні (негідник, пройдисвіт, зажерлива людина, українолюб, омріяний план) мовні засоби. 
Оцінювання відбувається шляхом уживання мовних одиниць, зареєстрованих у словниках або в пам'яті носіїв мови з погляду їхніх ціннісних орієнтирів: добра і зла, правди і неправди, справедливості i несправедливості, користі і шкоди, краси й потворності, дозволеного і забороненого. Оцінна семантика розкривається у відповідних контекстуальних умовах, зокрема в оновленні структури та семантики компонентів, стилістичної маркованості синтаксичних одиниць.

Поєднання логічної і емоційної оцінки уможливлює тісно пов'язану з ситуацією спілкування прагматичну оцінність тексту в цілому, зокрема мовні акти схвалення, заохочення, прихильності (плюс на шкалі оцінок) або навпаки осуду, зневаги (мінус на шкалі оцінок), які грунтуються на спільному фонді знань і норм співрозмовників.

У плані вираження оцінка може бути експліцитною й імпліцитною. Експліцитну оцінку передають мовні засоби з виразною безпосередньо позитивною або негативною конотацією, а імпліцитні потребують складнішого і глибшого опосередкованого процесу сприймання.

Стилістичний потенціал оцінності в тексті розкривається на лексичному, фразеологічному, синтаксичному рівнях (Космеда 123). Тексти різні за стилем і змістом різняться за способом вираження в них оцінності.

Для наукового стилю характерна раціональна оцінність, яка регулює засвоєння, систематизацію і перетворення попередніх досягнень у галузі знань, стимулює пошук нових ідей і мотивує досягнення нових результатів. Позитивно оцінюється наукове відкриття за умови наявності новизни, актуальності, достовірності, точності, логічності, а негативно у разі відсутності цих критеріїв. Оцінність у науковому тексті переважно позитивнооцінна і має сформовану стандартизовану парадигму мовних засобів (значний доробок, переконливий результат, авторитетне джерело, грунтовна праця). Негативноцінну парадигму наукового тексту формують антонімічні словосполучення (непереконливі докази, неавторитетна праця, необгрунтовані висновки). Особливу роль оцінність виконує в науковій рецензії, де об'єктом аналізу є аспекти, методи дослідження, його теоретичне і практичне значення (академічна праця, адекватні методи, достовірна класифікація, показовий аналіз).

В офіційно-діловому стилі також переважає раціональна оцінність, базовими одиницями якої є дієслова покращити, поліпшити і віддієслівні іменники покращення, поліпшення. Ядром таких текстів є позитивнооцінна (ефективність, прогрес, досягнення, раціональний, продуктивний, належний) i негативноцінна (негативний, невиправданий, неефективний, неналежний) лексика, кліше (суттєвий внесок, економічно обгрунтований, вкрай незадовільний). В офіційно-ділових текстах можливе вживання раціональноемоційних висловлювань (збалансована система, зручний графік, планомірний розвиток). Показовим для них $є$ модальність повинності, 
обов'язку (Установа зобов'язана до кінця поточного кварталу розробити план розвитку пріоритетних напрямів дослідження).

Оцінність у публіцистичному стилі забезпечує одну з його основних функцій - впливу на масову свідомість суспільства. Публіцистичні тексти $\epsilon$ сферою обміну інформацією, раціонального й емоційного оцінювання понять, явищ світу, вираження ціннісних орієнтирів певного колективу, політичної, ідеологічної групи людей, суспільства в цілому. Раціональну оцінність формують відомі для носіїв мови із загальнолюдського або національного досвіду позитивнооцінні і негативнооцінні слова (справедливість, патріотизм, демократія, національно-свідомий, відповідальний - несправедливість, тоталітаризм, тероризм, агресія, жорстокий), які будують позитивнооцінну (держава - незалежна, самостійна, соборна, суверенна, демократична, переможна, європейська, вільна, нова; народ: національно-свідомий, непереборний, сильний, цілеспрямований, інтелектуальний, європейський, успішний, єдиний, об'єднаний, нездоланний, культурний, піднесений; влада - відповідальна, державницька, патріотична) і негативноцінну (держава - тоталітарна, антигуманна, залежна; народ - несвідомий, некультурний; влада безвідповідальна, антидержавницька, розкоординована, корумпована) парадигми ядерних понять (держави, народу, влади) публіцистичних текстів. Навколо ядерних понять у публіцистичних текстах вибудовується експліцитний емоційно-оцінний публіцистичний словник (публіцистична лексика) i висловлення (народ - багатостраждальний, заляканий, понівечений, пригнічений, забитий, затоптаний, зрусифікований, обкрадений, зайвий, суржиковий, краплений, мічений, безсилий, безликий знедуховлений,; влада - бандитська, перевтомлена, політичні аферисти, перебіжчики, зрадники, тушки, кровопивці). Експліцитна оцінка $\epsilon$ виразною ознакою полеміки, критичного аналізу суспільно-політичних, економічних, культурних процесів і виразно простежується на лексичному рівні, зокрема в синонімічних рядах, в яких завжди представлені слова більш нейтрального значення, а також одиниці з різними емоційно-оцінними відтінками. Кожна доба спричиняється до виникнення нових реалій, пізнання нових явищ, отже, й формування нових понять. Проте не тільки нові явища потребують осмислення і словесного вираження, старі поняття також із плином часу змінюються, їх розуміння прямо пов'язане 3 динамікою цінностей суспільства - це природна взаємозалежність поняттєвого і словесного світів.

Закономірні процеси розвитку мови потребують оновлення лексичних засобів, вираження різних відтінків значення. Як наслідок розширюються наявні і виникають нові синонімічні ряди з неоднорідним планом вираження i різними функціями (заміщення, уточнення, поглиблення характеристики предмета): знедуховлений - обездуховлений пустодухий, знеосіблення - деперсоналізація (Російському шовінізмові відводиться... особлива роль у нівеляції $і$ знеосібленні українців 
(Літературна Україна, 17 червня 2012); «Гранословці» (сучасники письменницького конкурсу «Гранослов») не зупиняються на констатації екзистенціальної проблематики, не перетворюються на пасивних споглядальників нівеляції самооцінної особистості в зародку, що активно відбувалося в процесі запрограмованої деперсоналізації народу (Культура і життя, 27 квітня 2013)).

Експліцитну функцію виконують синонімічні й антонімічні епітети, які в тексті наголошують на якості, властивості, увиразнюють позитивнооцінні або негативнооцінні характеристики осіб, явищ життя. У мові публіцистичного стилю як синоніми функціонують позитивнооцінні епітети до слів народ, нація, суспільство (одухотворений - одуховлений; Наша нація, одухотворена вірою в добро і справедливість, здолає всі труднощі і незгоди, досягне єдності і розквіту (Україна молода, 06 вересня 2012); Упродовж якого десятка років цікавило мене суспільство епохи Середньовіччя не те темне, як його звичайно уявляють, а одуховлений вірою народ, душа якого втілилася в камені соборів та романських $i$ готичних скульптур» (Літературна Україна, 04 жовтня 2012). 3 плином часу коло епітетів, які означують процеси і явища світу розширюються, змінюється.

Імпліцитну оцінність у публіцистичних текстах зумовлює синтаксична будова: зміна порядку слів, парцельовані, приєднувальні конструкції, еліпсиси. Граматичні засоби створення аксіології вислову, на відміну від лексико-семантичних і фразеологічних, не мають прямого зв'язку з позитивною або негативною оцінкою. Вони виконують функцію наповнення тексту інформативністю, часто суб'єктивною, яка спонукає читача до певних оцінних асоціацій. Оцінними синтаксичними одиницями $€$ розчленовані структури, тобто спеціально вичленовані з одного речення два і більше виразно оформлених висловлення. Найпоширенішою з них у мові публіцистичного стилю $є$ парцеляція, яка уможливлює привернення уваги читача на певній частині речення, посилює інформативну, оцінну місткість синтаксичної одиниці (Нас мирних гречкосіїв упосліджували. А ми винайшли світове зерно і колесо, конституцію і демократію (Літературна Україна, 10 квітня 2014).

Одним із різновидів синтаксичної оцінності $є$ називний уявлення називний відмінок іменника, який дає позитивну або негативну оцінку предметам, явищам, названим цими іменниками (Доленосна зустріч; Гібридна війна).

Для уточнення, доповнення оцінки предмета або явища, роз'яснення змісту, введення додаткової інформації у публіцистичних текстах функціонують вставні і вставлені конструкції (Ті фахівці справді дали старт (лише старт, але важливий старт) реформам у міліції переходу до формату цивілізованої поліції. $А$ далі кавказькі реформатори повтікали, жахнувшись масштабів корупції в своєму міністерстві (Літературна Україна, 09 березня 2017). Їх функціональне навантаження полягає в додатковій інформації, що розширює й збагачує зміст висловлювання. 
Імпліцитними засобами оцінювання на стилістичному рівні $\epsilon$ метафора, метонімія, які в публіцистичному тексті через асоціативні зв'язки акцентують на новому в оцінці процесів доби, відбивають переосмислення історичного минулого і сучасних реалій життя народу (Згущені ріки українських політиків або про приховані складники улюблених ласощів малюків (Україна молода, 13 грудня 2012); «Божественна» стратегія державних чиновників вигрілась на сонечку і активно допомагає конфесійній афері з «прихватизації» пам'ятки національного значення - Старокиївської гори та руїн Десятинної церкви (Україна молода, 04 грудня 2012)).

Оцінка явищ духовного життя народу часто знаходить вираження в метафоричній енантіосемії - поляризації значень слів, зокрема чітко вираженої і вже усталеної в свідомості людей негативної семантики поняття політика і позитивно окресленої в усі періоди історії літературної мови культурної сфери життя суспільства (Сучасні кобзарі з намулу часу, ідеології, політики та імітації вимивають золоті піщинки правдивого кобзарства (Слово Просвіти, 22-28 серпня 2013)). Протиставлення позитивних і негативних оцінок досягається за допомогою стилістичного засобу - антитези, що полягає в зіставленні порівнюваних понять, явищ, ситуацій через поєднання їх значень в одному контексті для досягнення виражально-зображального ефекту, зокрема увиразнення протилежності (В Україні зараз набирає силу процес очищення, у Росії - прощес загнивання (Україна молода, 24 червня 2014)).

Оцінні функції виконує також порівняння, що передає позитивне або негативне ставлення до об'єкта через найхарактерніші ознаки, які органічно властиві для інших предметів чи явищ (Влада - це підліток, який постійно шукає і розширює межі своєї безвідповідальності. А суспільство, подібно до дорослого, ці межі встановлює і контролює всередині (Радіо Свобода, 31 липня 2013). Багатовимірність функціонального вживання оцінних засобів мови унеможливлює їх чітку класифікацію за єдиною ознакою, що особливо помітне в переході оцінної лексики в оцінні синтаксичні структури (Коць 278).

Показовим для публіцистичного стилю $є$ вживання емоційно-оцінних трансформованих фразеологізмів (Жайворонок 445), які актуалізують знання про сучасні політичні реалії (Перспективи невеселі, але світло в кінці тунелю бачу (Молодь України, 11 січня 1994); ... латають чергові бюджетні діри за рахунок наших сімейних бюджетів (Перець, № 6, 2000)). Метафоризовані трансформовані фразеологізми в заголовкових структурах публіцистичних текстів загострюють увагу читача і спонукають прочитати статтю, зміст якої розкриває сам об'єкт аналізу і оцінки (Між солом'яних вогнів ідей і швидкого попелу забуття. Українська зовнішня політика. Погляд з-за кордону (Час Тіме, 17 січня 1997)). Чим більше у значенні фразеологічної одиниці міститься потрібної інформації, яка відповідає властивостям об'єкта, тим більша ймовірність того, що читач залишить її у своїй свідомості. 
Для розмовного стилю характерна емоційна оцінність, яка посилюється інтонацією, емоційними вигуками, емоційно-експресивною лексикою, експресивним порядком слів. Ефект вияву експліцитної емоційної оцінки створюють поєднання у висловленні 1) раціональнооцінної лексики з прислівниками міри і ступеня (жахливо, страшно, здорово, добре/погано); 2) раціонально-оцінних слів із плеоназмами так, такий, які додають висловленню інтонаційного компоненту (так неможливо, так корисно, так вигідно, такий неймовірний, такий впевнений, такий вдалий, такий розумний); уживання 1) суб'єктивномодальних синтаксичних конструкцій (Кому це треба!; 3 якого це дива!; Це чиясь забаганка!); 2) жаргонізмів з оцінним значенням (Класний фільм; Це був крутий виступ).

Емоційна оцінність переважає і в художньому стилі. Раціональнооцінна лексика набуває емоційної конотації в контекстуальному вживанні. Показовим $є$ поєднання нейтральної лексики з прямим або непрямим сигналом емоційності, як-от у романі В. Шкляра «Чорний Ворон»: Добре наобідані гості (бо де ще та святкова вечеря!) - червонопикі, масні, розпашілі, в парадних френчах, рипучих чоботях і портупеях, - лінькуватовесело козиряли один одному, ручкалися, щось там собі погукували для годиться й повагом сходили на ганок. Основним засобом вираження оцінності в художніх текстах $є$ вживання нейтральної лексики з оцінною конотацією, наприклад, у «Тигроловах» І. Багряного: Прощались із землею, прощались із усім. А ввіччю, либонь, стояв відтворений образ того, хто не здався, хто лишився таки там. Образ, як символ непокірної і гордої молодості, символ тієї волелюбної і сплюндрованої за те Вітчизни....

Конкретний оцінний зміст у художньому тексті може не збігатися із загальномовним і часто прочитується лише в широкому контексті.

Для релігійного стилю показовим $є$ емоційно-оцінна тональність тексту, яку формують образні позитивнооцінні й негативнооцінні парадигми полярних релігійних понять з абстрактною семантикою: добра - зла, благодаті - гріха (Хоча егоїстичні люди можуть зробити багато добрих вчинків. Всі вони будуть прикрашені славою, самозахопленням, самовдоволенням, гордістю за зроблене і т.д. і що тоді стається далі? Цей блиск $\epsilon$ проминаючим. Добро зроблене із таким блиском стане добром проминаючим. Наслідком якого може бути велике зло (Духовні роздуми, 16 грудня 2007)).

Висновки та перспективи досліджень. Отже, оцінність - категорія динамічна і прямо пов'язана зі специфікою розвитку літературної мови, зі зміною суспільно-політичних і культурних умов життя суспільства, його ціннісних орієнтирів. Постійно змінювана дійсність вимагає нових моделей для іï інтерпретації. Оцінність $\epsilon$ узагальненим ціннісним орієнтиром соціуму в конкретний історичний період його розвитку. 


\section{Список використаної літератури}

Арутюнова, Надежда. «Аксиология в механизмах жизни и языка». Проблемы структурной лингвистики 1982. Москва: Наука, 1984.

Вольф, Елена. Функциональная семантика оценки. Москва: Наука, 1985.

Єрмоленко, Світлана. «Експресивність». Украӥнська мова: енциклопедія, за ред. ред. В. М. Русанівського, і О. О. Тараненка. Київ, 2000, с. 156-7.

Жайворонок, Віталій. «Парцеляція». Украӥнська мова: енциклопедія, за ред. ред. В. М. Русанівського, і О. О. Тараненка. Київ, 2000, с. 461.

Ивин, Александр. Основания логики оценок. Москва, 1970.

Іваненко, Світлана. Поліфонія тексту. Київ: Видавничий центр КДЛУ, 1999.

Космеда, Тетяна. Аксіологічні аспекти прагмалінгвістики: бормування і розвиток категорії оцінки. Львів, 2000.

Коць, Тетяна. Українське слово в пресі кінця XIX - початку XXI ст.: динаміка літературної норми. Київ: Видавництво Дмитра Бураго, 2018.

Сорока, Тетяна. Особливості полісемантичної структури аксіономенів сучасної англійської мови. Сучасні дослідження з іноземної філології, вип. 13, 2015, с. 197-208.

Столярова, Зинаида. Лексико-семантическое поле оценки в разговорной речи. Словарные категории. Москва, 1988, с. 161-6.

Чернушко, Наталія. Про розвиток лінгвістичних поглядів на конструкції експресивного синтаксису. Лінгвістичні студії на пошану корифею. Харків, 2014.

Fix, Uell. 'Kommunicativ adaguat' - 'stilistisch adaguat'. Zu Problemem, Kategorien, Kriterien der Redebwertung. Dissrtation (B) zur Erlangung des akademischen Grades doctor scientiae philosophiae. Halle-Wittenberg: Martin-Luther-Universitat, 1988.

Wierzbicka, Anna. Understanding cultures through their key words: English, Russian, Polish, German, and Japanese. New York: Oxford University Press, 1997.

\section{References}

Arutjunova, Nadezhda. "Aksiologija v mehanizmah zhizni i jazyka". Problemy strukturnoj lingvistiki 1982. Moskva: Nauka, 1984.

Vol'f, Elena. Funkcional'naja semantika ocenki. Moskva: Nauka, 1985.

Yermolenko, Svitlana. "Ekspresivnist". Ukrainska mova: entsyklopediia, edited by V. M. Rusanivskyi, and 0. O. Taranenko. Kyiv, 2000, pp. 156-7.

Zhajvoronok, Vitaliy. "Parcelyaciya". Ukrainska mova: entsyklopediia, edited by V. M. Rusanivskyi, and 0. O. Taranenko. Kyiv, 2000, p. 461.

Ivin, Aleksandr. Osnovanija logiki ocenok. Moskva, 1970.

Ivanenko, Svitlana. Polifoniya tekstu. Kyiv: Vidavnichij centr KDLU, 1999.

Kosmeda, Tetiana. Aksiologichni aspekti pragmalingvistiki: formuvannya i rozvitok kategoriyi ocinki. Lviv, 2000.

Kots, Tetiana. Ukrayinske slovo v presi kincya XIX - pochatku XX st.: dinamika literaturnoyi normy. Kyiv: Vidavnictvo Dmitra Burago, 2018.

Soroka, Tetiana. "Osoblivosti polisemantichnoyi strukturi aksionomeniv suchasnoyi anglijskoyi movi”. Suchasni doslidzhennya z inozemnoyi filologiyi, iss. 13, 2015, pp. 197-208.

Stolyarova, Zinaida. "Leksiko-semanticheskoe pole ocenki v razgovornoj rechi". Slovarnye kategorii. Moskva, 1988, pp. 161-6.

Chernushko, Nataliya. "Pro rozvitok lingvistichnih poglyadiv na konstrukciyi ekspresivnogo sintaksisu". Lingvistichni studiyi na poshanu korifeyu. Harkiv, 2014.

Fix, Uell.'Kommunicativ adaguat' - 'stilistisch adaguat'. Zu Problemem, Kategorien, Kriterien der Redebwertung. Dissrtation (B) zur Erlangung des akademischen Grades doctor scientiae philosophiae. Halle-Wittenberg: Martin-Luther-Universitat, 1988.

Wierzbicka, Anna. Understanding cultures through their key words: English, Russian, Polish, German, and Japanese. New York: Oxford University Press, 1997. 